\title{
Nationwide system to centralize decisions around ECMO use for severe COVID-19 pneumonia in Japan (Special Correspondence)
}

\author{
Japan ECMOnet for COVID-19
}

\begin{abstract}
The novel coronavirus disease 2019 (COVID-19) is spreading in Japan. We have collected a total of 26 patients with COVID-19 who required extracorporeal membranous oxygenation (ECMO). The available data from the first 14 cases demonstrated that the median age of patients was 71 and the median $\mathrm{PaO}_{2} / \mathrm{FIO}_{2}$ ratio, positive end-expiratory pressure, mean airway pressure, and lung compliance were 70, $15 \mathrm{cmH}_{2} \mathrm{O}, 21 \mathrm{cmH}_{2} \mathrm{O}$, and $28 \mathrm{~mL} / \mathrm{cmH}_{2} \mathrm{O}$, respectively. Median serum KL-6 level was $333 \mathrm{U} / \mathrm{mL}$. Consequently, 16 (62\%) out of the 26 have been weaned off and $6(26 \%)$ have been extubated and on rehabilitation, while the other 10 (38\%) remain on ECMO. There seemed to be two phenotypes of COVID-19: one with impaired lung compliance and one with preserved lung compliance. The latter phenotype was likely to be favored from the use of ECMO. Further investigation is necessary to clasrify the optimal use of ECMO in patients with COVID-19.
\end{abstract}

Keywords: Mechanical ventilation, Compliance, Acute respiratory failure, KL-6, Prognosis

\section{Main Text}

The novel coronavirus disease 2019 (COVID-19) is spreading in Japan. The number of patients who need extracorporeal membranous oxygenation (ECMO) is expected to increase; however, the clinical characteristics of the patients who require and will benefit from ECMO are unclear [1].

On February 15, the Japanese Society of Intensive Care Medicine (JSICM), the Japanese Association for Acute Medicine (JAAM), the Japanese Society of Respiratory Care Medicine (JSRCM), and the Japanese Society of PCPS/ ECMO (JSPCPS/ECMO) launched "Japan ECMOnet for COVID-19" as a telephone consultation, treatment support,

\section{Correspondence: shinhiro@nms.ac.jp}

Japan ECMOnet for COVID-19 Japanese Society of Intensive Care Medicine, the Japanese Association for Acute Medicine, the Japanese Society of Respiratory Care Medicine, and the Japanese Society of PCPS/ECMOhttps:// jintensivecare.biomedcentral.com/articles/10.1186/s40560-020-00440-9 and a web-based real-time nationwide registry and surveillance system to discuss COVID-19 patients from over 400 hospitals who may be candidates for ECMO [2]. The initiative is led by more than 20 ECMO experts (Japan ECMOnet for COVID-19) from all over Japan.

As of March 15, there have been 26 patients who were placed on ECMO based on deliberation of the group. Sixteen out of the 26 (61.5\%) have been weaned off and six have been extubated and on rehabilitation, while the rest remain on ECMO. A few of these patients who have been weaned off ECMO still need treatment for other organ failures.

We report the data from the first 14 cases. The median age of the patients is 71 (range $45-81$ years). The median number of days between intubation and ECMO was 3 days (range $0-9$ days). The median $\mathrm{PaO}_{2} / \mathrm{FIO}_{2}$ ratio, PEEP, mean airway pressure, and lung compliance before initiation of ECMO were 70 (range 52-147), 15 
$\mathrm{cmH}_{2} \mathrm{O}$ (range $\left.10-18 \mathrm{cmH}_{2} \mathrm{O}\right), \quad 21 \mathrm{cmH}_{2} \mathrm{O} \quad(18-27$ $\mathrm{cmH}_{2} \mathrm{O}$ ), and $28 \mathrm{~mL} / \mathrm{cmH}_{2} \mathrm{O}$ (range $13.6-70 \mathrm{~mL} / \mathrm{cmH}_{2} \mathrm{O}$ ), respectively. Selected laboratory data of the patients on admission were as follows: median serum KL-6 (a marker of interstitial pneumonia) was $333 \mathrm{U} / \mathrm{mL}$, LDH was 460 $\mathrm{IU} / \mathrm{L}$, and procalcitonin was $0.12 \mathrm{ng} / \mathrm{mL}$. With regard to ECMO settings, the median blood flow was $4 \mathrm{~L} / \mathrm{min}$ (range $2.5-5.3 \mathrm{~L} / \mathrm{min}$ ), the median size of the draining cannula was 24 Fr (range 21-25 Fr), and the median size of the infusing cannula was 20 Fr (range 16-21 Fr). For anti-viral treatment, lopinavir was used for 13/14 (93\%) patients. All patients received empirical antibiotics (carbapenems or $3 \mathrm{rd} / 4$ th generation cephalosporins). Ciclesonide, a glucocorticoid inhaler, was used for $4 / 13$ (31\%) of the cases. The effectiveness of any of the medications cannot be assessed at this time.

Experts within Japan ECMOnet for COVID-19 identified two phenotypes of patients with severe pneumonia: one associated with low lung compliance and another with preserved lung compliance. Oxygenation of patients with preserved lung compliance did not improve with higher PEEP. For these patients, the serum KL-6, SP-D (another marker of interstitial pneumonia), and LDH were not elevated on admission.

These findings suggest that lung fibrosis was not severe for this subgroup of patients. The adoption of a platform for real-time discussion to guide the use of a scarce resource such as ECMO has been valuable to the Japanese doctors who are caring for critically ill patients with COVID-19 infection. A central near-real-time data repository is optimal to perform just-in-time epidemiologic studies and to develop algorithms that can inform clinical decision-making.

\footnotetext{
Abbreviations

COVID-19: Coronavirus disease 2019; ECMO: Extracorporeal membranous oxygenation; $\mathrm{FlO}_{2}$ : Fraction of inspired oxygen; JAAM: The Japanese Association for Acute Medicine; JSRCM : The Japanese Society of Respiratory Care Medicine; JSICM: The Japanese Society of Intensive Care Medicine: LDH: Lactate dehydrogenase; $\mathrm{PaO}_{2}$ : Partial pressure of arterial oxygen; PCPS: Percutaneous cardiopulmonary support; PEEP: Positive end-expiratory pressure; SP-D: Surfactant protein-D
}

\footnotetext{
Acknowledgements

Contributors to the research: Ryuzo Abe, MD, PhD; Yuji Fujino, MD, PhD, JSRCM (chair); Kenji Fujizuka, MD; Yoshihiro Hagiwara, MD; Yoshitaka Hara, MD, PhD; Satoru Hashimoto, MD, PhD, Japan web-based real-time nationwide registry for COVID-19 (chair); Noriyuki Hattori, MD, PhD; Takanari Ikeyama, MD; Shingo Ichiba, MD, PhD; Wataru Iwanaga, MD; Yoshiaki Iwashita, MD, PhD; Hitoshi Kaneko, MD; Kaneyuki Kawamae, MD, PhD; Tomoyuki Nakamura, MD; Osamu Nishida, MD, PhD, JSICM (chair); Masaji Nishimura, MD, PhD, JSICM (former chair); Naoto Morimura, MD, PhD; Takayuki Ogura, MD, PhD; Shinichiro Ohshimo, MD, PhD; Keisuke Oyama, MD; Keibun Liu, MD, PhD; Tetsuya Sakamoto, MD, PhD, JSPCPS/ECMO (co-chair); Junichi Sasaki, MD, PhD; Yoshiki Sawa, MD, PhD, JSPCPS/ECMO study group (co-chair); Ryutaro Seo, MD; Takeshi Shimazu, MD, PhD, JAAM (chair); Nobuaki Shime, MD, PhD; Keiki Shimizu, MD; Hiroyuki Suzuki, MD; Shinhiro Takeda, MD, PhD, Japan ECMOnet for COVID-19 (chair); and Ichiro Takeuchi, MD, PhD. This report has been authorized by the Japanese Society of Intensive Care Medicine and the Japanese Association for Acute Medicine for simultaneous
}

publication in their official journals Acute Medicine \& Surgery and Journal of Intensive Care.

\section{Authors' contributions}

All co-authors collected the data presented in this study. Yl, SH, and ST have drafted the manuscript. ST coordinated this study. SO prepared the manuscript for submission. The author(s) read and approved the final manuscript.

\section{Funding}

Nothing.

Availability of data and materials

Not applicable.

Ethics approval and consent to participate

Not applicable.

\section{Consent for publication}

All co-authors have approved the manuscript and agreed with the publication.

\section{Competing interests}

The authors have no conflict of interest to declare.

Accepted: 31 March 2020

Published online: 24 April 2020

\section{References}

1. MacLaren G, Fisher D, Brodie D. Preparing for the most critically ill patients with COVID-19: the potential role of extracorporeal membrane oxygenation. JAMA. Published online February 19, 2020. https://doi.org/10.1001/jama. 2020.2342 .

2. Japan ECMOnet for COVID-19. Japan COVID-19 ECMOnet: Telephone consultations for cases with severe respiratory failure caused by COVID-19. J Intens Care. 2020. In press.

\section{Publisher's Note}

Springer Nature remains neutral with regard to jurisdictional claims in published maps and institutional affiliations.

Ready to submit your research? Choose BMC and benefit from

- fast, convenient online submission

- thorough peer review by experienced researchers in your field

- rapid publication on acceptance

- support for research data, including large and complex data types

- gold Open Access which fosters wider collaboration and increased citations

- maximum visibility for your research: over $100 \mathrm{M}$ website views per year

At BMC, research is always in progress.

Learn more biomedcentral.com/submission 